\title{
MANAGEMENT OF A PATIENT WITH THERMAL BURNS AND PARA-CHLORONITROBENZENE POISONING
}

\author{
ZHANG YUANHAI ${ }^{1}$, WANG XINGANG ${ }^{2}$, NI LIANGFANG ${ }^{1}$, JIANG RUIMING ${ }^{1}$, LIU LIPING', \\ YE CHUNJIANG $^{1}$, and HAN CHUNMAO ${ }^{2}$
}

${ }^{1}$ Zhejiang Quhua Hospital, Quzhou, China

Department of Burn and Plastic Surgery

${ }^{2}$ 2nd Affiliated Hospital of Zhejiang University, Hangzhou, China

College of Medicine, Department of Burns \& Wound Care Centre

\begin{abstract}
Para-chloronitrobenzene (p-CNB), a hazardous and toxic substance, is widely used as an intermediary in chemical industries. $\mathrm{p}$ - $\mathrm{CNB}$ can cause methaemoglobinaemia due to electron-withdrawing properties of the nitro and chlorine groups. We present a case of a 23 -year-old man suffering from thermal burns and p-CNB poisoning. In this case, severe methaemoglobinaemia was caused by the absorption of p-CNB through the burn wounds. Despite active treatment, such as the antidote of methylene blue, the patient's methaemoglobinaemia progressed, with slowly increasing methaemoglobin $(\mathrm{MetHb})$ level. This case highlights the complexity and difficulty of managing this type of injury. To our knowledge, this case can be the first case report describing methaemoglobinaemia induced by $\mathrm{p}$-CNB in a patient with thermal burns.
\end{abstract}

Key words:

Chemical burns, Methaemoglobinaemia, Methylene blue, Para-chloronitrobenzene

\section{INTRODUCTION}

Chloronitrobenzenes, which are widely used as intermediaries for chemical syntheses of drugs, herbicides, dyes and other products, have 3 isomers: ortho- (o-CNB), meta- (m-CNB), and para-chloronitrobenzene $(\mathrm{p}-\mathrm{CNB})$ [1]. Of these, $\mathrm{p}-\mathrm{CNB}$ is the most toxic one [2]. It is a yellow crystalline compound that is freely soluble in boiling alcohol, ether and in carbon disulphide, but is insoluble in water [3].
Para-chloronitrobenzene is also a hazardous material, which can cause methaemoglobinaemia in humans and animals due to electron-withdrawing properties of the nitro and chlorine groups $[1,4]$. Severe methaemoglobinaemia can be a life-threatening condition [5]. In addition, $\mathrm{p}$-CNB is weakly mutagenic and carcinogenic [6,7]. However, few reports describe methaemoglobinaemia induced by $\mathrm{p}-\mathrm{CNB}$. To our knowledge, no case of thermal burns combined with $\mathrm{p}$-CNB poisoning has

Received: January 16, 2014. Accepted: June 5, 2014.

Corresponding author: X. Wang, 2nd Affiliated Hospital of Zhejiang University, College of Medicine, Department of Burns \& Wound Care Centre, 88 Jiefang Road, Shangcheng District, Hangzhou, China (e-mail: wxg8157@163.com). 
been reported recently. Therefore, it seemed important to describe this clinical case.

\section{CASE DESCRIPTION}

A 23 -year-old male, weighing $61 \mathrm{~kg}$, suffered from a scald by the heated liquid of $\mathrm{p}-\mathrm{CNB}\left(120^{\circ} \mathrm{C}\right)$, which resulted in the 2nd-degree burns to $20 \%$ of the total body surface area (TBSA), affecting his face, neck, right chest and right upper limb. After irrigating the area with water for $\sim 15 \mathrm{~min}$ in the workshop, and $3 \mathrm{~h}$ post-burn he was taken to our Emergency Department (ED). When he arrived at the ED, his blood pressure was $110 / 70 \mathrm{~mm} \mathrm{Hg}$, pulse -87 beats/min, respiratory rate - 20 breaths/min, and oxygen saturation via pulse oximetry $\left(\mathrm{SpO}_{2}\right)$ on the room air $-92 \%$. But the value of $\mathrm{SpO}_{2}$ declined rapidly to $84 \%$. The patient was tired, had dyspnoea, and obviously, had cyanotic skin, lips and nail beds. The majority of burn wounds turned black red as the blisters exfoliated, although some other areas were contaminated with light yellow chemical particles.

Partial results of blood tests, including routine examinations, arterial blood gas (ABG) analysis, and electrolytes are listed in Table 1. When drawing blood for the tests, the blood was chocolate brown and did not turn red on vigorous shaking. Renal and liver function and serum electrolytes were normal. The percentage of MetHb in the blood was $11 \%$ (normal $\sim 1 \%$ ). Chest X-ray and electrocardiogram (ECG) were normal.

Based on the detailed history, clinical manifestations and laboratory results after admission, second-grade burns to $20 \%$ of the TBSA, and chemical poisoning were immediately suspected. In addition to the routine critical care and oxygen support (first, via nasal cannula, and then via endotracheal intubation), our initial management consisted of the immediate intravenous administration of $120 \mathrm{mg}$ of methylene blue $(2 \mathrm{mg} / \mathrm{kg}$ ) over $5 \mathrm{~min}$, in order to maintain the patient's $\mathrm{SpO}_{2}$ above $80 \%$. Other actions included administration of $2 \mathrm{~g}$ of vitamin $\mathrm{C}$ every $8 \mathrm{~h}, 30 \mathrm{mg}$ of cytochrome $\mathrm{C}$ every $12 \mathrm{~h}$, and $20 \mathrm{mg}$ of dexamethasone every $12 \mathrm{~h}$. Skin that surrounded the wounds was 3 times cleaned thoroughly with $75 \%$ alcohol. The wound surfaces were irrigated and scrubbed carefully with a large quantity of water, until there were no macroscopical contaminants or pungent odour. Then, the wounds were covered with $1 \%$ sulfadiazine silver cream and gauze; the dressing was changed every other day. Blood samples were taken periodically to evaluate the MetHb levels, hepatic and renal function and $\mathrm{SaO}_{2}$.

Between the 2nd and 7th day after admission, the patient's situation fluctuated frequently, with intermittent cyanosis and dyspnoea. The $\mathrm{SpO}_{2}$ monitored by pulse oximetry was very low (Figure 1), but increased rapidly after infusion of $1 \mathrm{mg} / \mathrm{kg}$ of methylene blue. Subsequently, the patient's dyspnoea was temporarily alleviated. When the $\mathrm{SpO}_{2}$ declined below $80 \%$, administration of $1 \mathrm{mg} / \mathrm{kg}$ of methylene blue was repeated intravenously. On days 3, 5, and 7, fresh red cell suspensions (400 ml, $200 \mathrm{ml}$, and $600 \mathrm{ml}$, respectively) were transfused for support. During this period, the patient's MetHb levels rose slowly (Figure 1).

On day 8, the patient developed sudden, severe dyspnoea, accompanied by chest tightness and evident cyanosis. His vital signs included: core temperature $37.4^{\circ} \mathrm{C}$, heart rate -92 beats $/ \mathrm{min}$, blood pressure 149/94 mm Hg, respiratory frequency - 28 breaths/min, $\mathrm{SaO}_{2}-96.7 \%$, and $\mathrm{SpO}_{2}-69 \%$. The white blood cell (WBC) count was $26300 / \mathrm{mm}^{3}$, the platelet count $88000 / \mathrm{mm}^{3}$, and $\mathrm{MetHb}-42.8 \%$. After an intravenous injection of $2 \mathrm{mg} / \mathrm{kg}$ of methylene blue, the $\mathrm{SpO}_{2}$ increased quickly to $91 \%$. The chest X-ray was performed again to confirm no abnormalities. The patient's burn wounds had dissolved eschar. After removing the eschar and necrotic tissues, following the 2nd debridement, the red wound basement was exposed with evident bleeding. On day 9 the MetHb level of the patient 
Table 1. Initial laboratory profiles when sent to the emergency department

\begin{tabular}{lcc}
\hline \multicolumn{1}{c}{ Parameter } & Measure & Reference range \\
\hline Complete blood cell count & & \\
white blood cell count $\left(\times 10^{9} / \mathrm{l}\right)$ & 14.80 & $4.00-10.00$ \\
hemoglobin $(\mathrm{g} / \mathrm{dl})$ & 16.20 & $13.00-17.00$ \\
platelet count $\left(\times 10^{9} / \mathrm{l}\right)$ & 188.00 & $150.00-350.00$ \\
Electrolytes $(\mathrm{mmol} / \mathrm{l})$ & & \\
$\mathrm{Na}$ & 139.40 & $135.00-145.00$ \\
$\mathrm{~K}$ & 3.10 & $3.50-5.50$ \\
$\mathrm{Ca}$ & 1.85 & $1.75-2.25$ \\
$\mathrm{P}$ & 1.39 & $0.97-1.61$ \\
Chemical battery & & \\
aspartate transaminase $(\mathrm{IU} / \mathrm{l})$ & 19.00 & 40.00 \\
alanine transaminase $(\mathrm{IU} / \mathrm{l})$ & 29.00 & 40.00 \\
total bilirubin $(\mathrm{mg} / \mathrm{dl})$ & 20.30 & $1.70-20.50$ \\
creatinine $(\mu \mathrm{mol} / \mathrm{dl})$ & 110.00 & $44.00-133.00$ \\
glucose $(\mathrm{mmol} / \mathrm{l})$ & 19.38 & $3.90-6.10$ \\
urea nitrogen $(\mathrm{mmol} / \mathrm{l})$ & 6.70 & $3.20-7.10$ \\
Arterial blood gas analysis & & \\
pH & 7.37 & $7.35-7.45$ \\
partial pressure of carbon dioxide $(\mathrm{mm} \mathrm{Hg})$ & 40.60 & $35.00-45.00$ \\
partial pressure of oxygen $(\mathrm{mm} \mathrm{Hg})$ & 142.00 & $80.00-90.00$ \\
base excess & -1.50 & $23.00-29.00$ \\
bicarbonate $(\mathrm{mmEq} / \mathrm{l})$ & 23.80 & \\
oxygen saturation $(\%)$ & 99.10 & \\
\hline
\end{tabular}

was $12.6 \%$, and declined gradually to the normal range until the 14th day post-burn.

The patient was treated with antibiotics, which were adjusted based on the results of bacterial cultures and drug sensitivity. After day 8, the patient's symptoms improved gradually, and his wounds finished re-epithelization by day 29. In addition, the patient's hepatic function declined slightly, with an increasing alanine transaminase, which peaked (516 U/l) on day 16 and returned to normal by day 31 through the protective liver treatment. On day 35 , the patient was transferred to the rehabilitation department for further treatment.

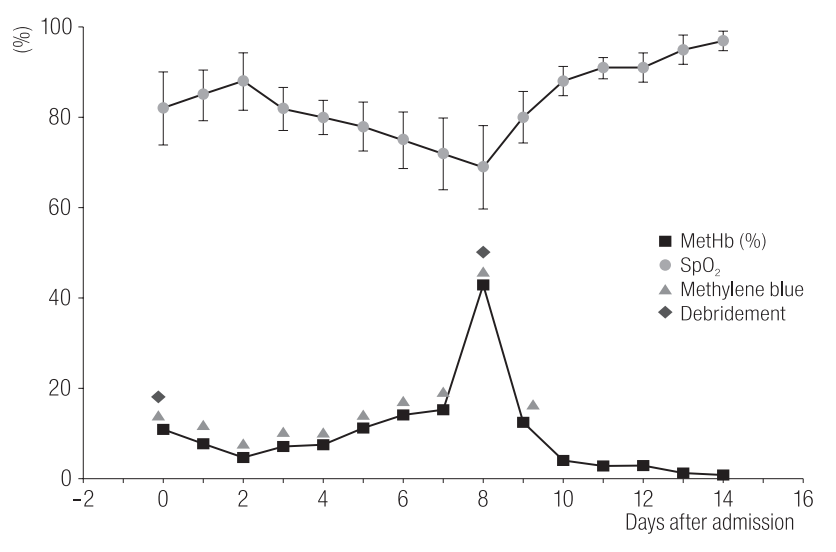

$\mathrm{MetHb}$ - methaemoglobin; $\mathrm{SpO}_{2}$ - oxygen saturation via pulse oximetry.

Fig. 1. The change trend of $\mathrm{SpO}_{2}$ and $\mathrm{MetHb}$ 


\section{DISCUSSION}

Para-chloronitrobenzene, an important industrial chemical, can induce methaemoglobinaemia by converting oxyhaemoglobin to MetHb [8]. Injuries caused by p-CNB are extremely rare. In 1977, Harrison described a patient with acute poisoning following ingestion of $\mathrm{p}-\mathrm{CNB}$, who developed severe toxic methaemoglobinaemia [9]. In 1985, Tabuchi et al. [10] reported that 11 longshoremen at Osaka South Port in Japan were poisoned with p-CNB after bags of the substance that were being loaded onto a ship accidentally tore; the lungs and skin were considered the main pathways of p-CNB absorption. Our patient got burnt by hot liquid of $\mathrm{p}-\mathrm{CNB}$, and lost the intact skin barrier as a consequence of thermal injury. The $\mathrm{p}-\mathrm{CNB}$ contaminated the wounds surface, and released a pungent odour. The broken skin barrier facilitated absorption of the poison, as documented in the literature [11]. Acute $\mathrm{p}-\mathrm{CNB}$ poisoning presenting with methaemoglobinaemia is an uncommon medical emergency.

According to the principals of treating chemical burns, there are 5 first aid measures: 1) removing the chemical agent, 2) treating any systemic toxicity and side-effects of the agent, 3) providing general support, 4) considering specific agents if appropriate, and 5) caring for the burns [12]. In the case of our patient with chemical burns, we emphasised respiratory support, removal of the chemical agent, administration of specific drugs to treat methaemoglobinaemia, and protection of vital organs.

Signs of impaired oxygen delivery, such as hypoxia and cyanosis, are often the first indicators of abnormal haemoglobin [13]. Methaemoglobinaemia should be suspected when cyanosis persists despite oxygen therapy, a low $\mathrm{SpO}_{2}$ with normal $\mathrm{ABG}$ oxygen saturation, and when "chocolate brown" blood fails to turn red on vigorous shaking [14]. On admission, although the nasal cannula was replaced by endotracheal intubation to provide $100 \%$ oxygen, the patient's signs and symptoms improved only little. Since methaemoglobinaemia was suspected, $2 \mathrm{mg} / \mathrm{kg}$ of methylene blue as a $1 \%$ solution was infused intravenously via a syringe pump. Methylene blue is the antidote of choice for acquired methaemoglobinaemia [15]. This increased the oxygen saturation via pulse oximetry above $80 \%$. While waiting for the laboratory results, the wounds were debrided and washed with water and $75 \%$ alcohol to remove any macroscopical chemicals on and around the wounds, until there were no obvious contaminants or odour.

The patient's $\mathrm{SpO}_{2}$ was low and fluctuated over a wide range, while the $\mathrm{ABG}$ analysis indicated that the $\mathrm{SaO}_{2}$ was always in the normal range. Tejesh et al. [16] have indicated that pulse oximetry readings are spurious and unreliable, and thus, suggested that patients with methaemoglobinaemia should be monitored using $\mathrm{ABG}$ rather than the traditional pulse oximetry. However, traditional pulse oximetry seemed more reasonable in our patient. At present, co-oximetry at 4 wavelengths has been regarded as the most accurate method for determining the oxygen content of blood, and has been used for the non-invasive measurement of MetHb levels $[13,17]$. Additionally, pulse co-oximetry at 8 wavelengths can be also selected for the non-invasive measurement of MetHb [18]. In the case of our patient, an invasive method was necessary to diagnose methaemoglobinaemia due to the limitations of measurement tools such as co-oximetry.

In the first week after admission, despite vigorous treatment, the patient remained unstable with intermittent cyanosis and dyspnoea. The MetHb level increased gradually, and methylene blue had little effect. On day 8, the MetHb level peaked, and the patient showed signs and symptoms of severe hypoxia. This might have been related to the explosive absorption of $\mathrm{p}-\mathrm{CNB}$ from the wounds surface. As known, $\mathrm{p}$-CNB is very lipophilic and could stick to wound eschar, making itself difficult to wash out. With the gradual dissolution of eschar, $\mathrm{p}-\mathrm{CNB}$ in the dissolved eschar was absorbed into the blood stream. On day 8 , massive eschar dissolved and released quantities of $\mathrm{p}-\mathrm{CNB}$, which 
were absorbed into the bloodstream and caused severe methaemoglobinaemia.

Furthermore, the existence of $\mathrm{p}-\mathrm{CNB}$ on the burn wounds could hinder normal healing of the 2nd-degree burns, which as a result took 29 days to heal completely. Because of the unstable situation of this patient after admission, more progressive surgical intervention had been put off. After the second debridement to remove the dissolved eschar and other necrotic tissues, the patient's situation converted quickly. It now seems that an earlier and more thorough debridement or surgical excision would have been more effective and beneficial for this patient. Additionally, catabolism of p-CNB is complicated [19], and the effect of metabolites of $\mathrm{p}$-CNB on methaemoglobinaemia is unknown.

\section{CONCLUSIONS}

In summary, this case report describes a successful management of a patient with thermal burns with methaemoglobinaemia. In this case, severe methaemoglobinaemia was caused by the absorption of $\mathrm{p}$-CNB through the burn wounds. Despite active treatment, including: respiratory support, immediate wound cleaning and intravenous infusions of methylene blue, the patient's methaemoglobinaemia progressed, with slowly increasing MetHb levels. All of these could be closely related to the characteristics of $\mathrm{p}-\mathrm{CNB}$. Since this type of chemical burn is rare, there was no reported experience to use as a reference. However, the integrated therapy might have been critical for the successful treatment of this patient. Among these, early and thorough surgical intervention is highly recommended.

\section{REFERENCES}

1. Xia S, Li H, Zhang Z, Zhang Y, Yang X, Jia R, et al. Bioreduction of para-chloronitrobenzene in drinking water using a continuous stirred hydrogen-based hollow fiber membrane biofilm reactor. J Hazard Mater. 2011;192(2):593-8, http:// dx.doi.org/10.1016/j.jhazmat.2011.05.060.

2. Watanabe T, Ishihara N, Ikeda M. Toxicity of and biological monitoring for 1,3-diamino-2, 4, 6-trinitrobenzene and other nitro-amino derivatives of benzene and chlorobenzene. Int Arch Occup Environ Health. 1976;37(3):157-68, http:// dx.doi.org/10.1007/BF00378415.

3. Yoshida T. Pharmacokinetic study of p-chloronitrobenzene in rat. Drug Metab Dispos. 1994;22(2):275-80.

4. Nair RS, Johannsen FR, Levinskas GJ, Terrill JB. Subchronic inhalation toxicity of p-nitroaniline and p-nitrochlorobenzene in rats. Fundam Appl Toxicol Off J Soc Toxicol. 1986; 6(4):618-27, http://dx.doi.org/10.1016/0272-0590(86)90174-0.

5. Whited C, Cohen SM. Nasal tetracaine spray-induced methemoglobinemia. Otolaryngol Head Neck Surg Off J Amn Acad Otolaryngol. 2012;146(4):678-9, http://dx.doi.org/ 10.1177/0194599811421124.

6. Shimizu M, Yasui Y, Matsumoto N. Structural specificity of aromatic compounds with special reference to mutagenic activity in Salmonella typhimurium - A series of chloro- or fluoro-nitrobenzene derivatives. Mutat Res Gen Toxicol. 1983;116(3-4):217-38, http://dx.doi.org/10.1016/01651218(83)90060-5.

7. Weisburger EK, Russfield AB, Homburger F, Weisburger JH, Boger E, van Dongen CG, et al. Testing of twentyone environmental aromatic amines or derivatives for long-term toxicity or carcinogenicity. J Environ Pathol Toxicol. 1978;2(2):325-56.

8. Li Q, Minami M, Inagaki H. Acute and subchronic immunotoxicity of p-chloronitrobenzene in mice. I. Effect on natural killer, cytotoxic T-lymphocyte activities and mitogen-stimulated lymphocyte proliferation. Toxicology. 1998;127(1-3):223-32, http://dx.doi.org/10.1016/S0300483X(98)00027-4.

9. Harrison MR. Toxic methaemoglobinaemia. A case of acute nitrobenzene and aniline poisoning treated by exchange transfusion. Anaesthesia. 1977;32(3):270-2, http://dx.doi. org/10.1111/j.1365-2044.1977.tb11608.x. 
10. Tabuchi T, Ham I, Minami M, Yamashiro H. Acute p-nitrochlorobenzene poisoning cases among stevedores at Osaka port. Proc Osaka Pref Inst Public Health Ed Md Health. 1985;23:25-30.

11. Zhang Y, Wang X, Liu L, Jiang R, Ye C, Ni L, et al. Hypercalcaemic crisis in a young man with extensive burns caused by heated $\mathrm{CaCl}_{2}$ solution: A case report. Burns. 2014; 40(3):e12-4, http://dx.doi.org/10.1016/j.burns.2013.08.026.

12. Palao R, Monge I, Ruiz M, Barret JP. Chemical burns: Pathophysiology and treatment. Burns. 2010;36(3):295-304, http://dx.doi.org/10.1016/j.burns.2009.07.009.

13. Cortazzo JA, Lichtman AD. Methemoglobinemia: A Review and recommendations for management. J Cardiothorac Vasc Anesth. Forthcoming August 2013, http://dx.doi. org/10.1053/j.jvca.2013.02.005.

14. Saxena H, Saxena AP. Acute methaemoglobinaemia due to ingestion of nitrobenzene (paint solvent). Indian J Anaesth. 2010;54(2):161-2, http://dx.doi.org/10.4103/0019-50 49.63635 .
15. Hall A, Stessel B, Bergmans D, Schnabel R. Two cases of acquired methemoglobinemia. Acta Anaesthesiol Belg. 2012;63(2):97-100.

16. Tejesh CA, Shivanna S, Manjunath AC, Prathima P. ICU management of methemoglobinemia due to unknown compound poisoning. J Anaesth Clin Pharmacol. 2013;29(1):139-40, http://dx.doi.org/10.4103/0970-91 85.105835 .

17. Ryoo SM, Sohn CH, Oh Bj, Kim WY, Lim KS. A case of severe methemoglobinemia caused by hair dye poisoning. Hum Exp Toxicol. 2013;33(1):103-5, http://dx.doi. org/10.1177/0960327113480973.

18. Feiner JR, Bickler PE. Improved accuracy of methemoglobin detection by pulse CO-oximetry during hypoxia. Anesth Analg. 2010;111(5):1160-7, http://dx.doi.org/10. 1213/ANE.0b013e3181f46da8.

19. Yoshida T, Tabuchi T, Andoh K. Pharmacokinetic study of p-chloronitrobenzene in humans suffering from acute poisoning. Drug Metab Dispos. 1993;21(6):1142-6.

This work is available in Open Access model and licensed under a Creative Commons Attribution-NonCommercial 3.0 Poland License - http://creativecommons.org/ licenses/by-nc/3.0/pl/deed.en. 